\title{
Influence of row spacing and harmfulness of weeds on yield and quality of flowers of German chamomile (Matricaria chamomilla L.) in spring sowing crops
}

\author{
Wpływ rozstawy rzędów i szkodliwości chwastów na plon \\ i jakość kwiatów rumianku pospolitego (Matricaria chamomilla L.) \\ w uprawach wiosennych
}

Alena Yakimovich*

\section{Summary}

Presence of weeds 20-30 days after spring sowing does not affect the flower yield of German chamomile (Matricaria chamomilla L.) grown at row spacing of 12.5 and $45 \mathrm{~cm}$. Weeds should be removed up to 40 days after the sowing, otherwise crop losses make up $24.0 \%$ at $12.5 \mathrm{~cm}$ row spacing and $30.8 \%$ at $45 \mathrm{~cm}$ row spacing, and 60 days after the sowing $50.8 \%$ and $74.0 \%$, respectively. Competition with weeds negatively affects chamomile vegetative mass loss (from 25.3 to $57.0 \%$ ) and the essential oil output per unit area is reduced by 19.6-31.5\% 40 days after the sowing and $49.8-74.1 \% 60$ days after the sowing.

Key words: German chamomile, weeds, harmfulness of weeds, flower yield loss

\section{Streszczenie}

Występowanie chwastów 20-30 dni po wiosennym siewie nie ma wpływu na wielkość plonu kwiatów rumianku pospolitego (Matricaria chamomilla L.) uprawianego w rozstawie rzędów 12,5 i $45 \mathrm{~cm}$. Odchwaszczanie należy przeprowadzić do 40 dni po siewie, w przeciwnym razie straty plonów wynoszą $24,0 \%$ w uprawach rumianku pospolitego w rozstawie rzędów $12,5 \mathrm{~cm}$ i 30,8\% w rozstawie rzędów $45 \mathrm{~cm}$, a 60 dni po siewie odpowiednio 50,8\% i 74,0\%. Konkurencja z chwastami negatywnie wpływa na ilość masy zielonej (biomasy) rumianku pospolitego (z 25,3 do 57,0\%) oraz wydajność olejków eterycznych, których zawartość w przeliczeniu na jednostkę powierzchni zmniejsza się odpowiednio o $19,6-31,5 \% 40$ dni po siewie i 49,8-74,1\% 60 dni po siewie.

Słowa kluczowe: rumianek pospolity, chwasty, szkodliwość chwastów, obniżka plonu kwiatów

RUE Institute of Plant Protection

2 Mira Street, a/c Priluki BY - 223011

Minsk District, Minsk Oblast

Republik of Belarus

*corresponding author: belizr@tut.by 


\section{Wstęp / Introduction}

German chamomile [Matricaria chamomilla L., Matricaria recutita L., Chamomilla recutita (L.) Rauschert] is a medicinal plant that is native to Southern and Western Europe and Northwest Asia. It grows in Germany, Hungary, France, Russia (Upadhyaya et al. 2016) and in Belarus; the farm "Bolshoe Mozheykovo" (300 ha) is the main area of its cultivation. German chamomile has been also cultivated in North Africa, North America, and other parts of the world.

The dry flowers of chamomile contain 120 secondary metabolites, comprising terpenoids: $\alpha$-bisabolol, $\alpha$-bisabolol oxide A and B, chamazulene, sesquiterpenes; coumarins; flavonoids; spiroethers and other components such as tannins, anthemic acid, choline, polysaccharides and phytoestrogens. The essential oil of chamomile has a light blue color due to the terpenoid chamazulene. Chamazulene is about $5 \%$ of the essential oil (Srivastava et al. 2010; Sharafzadeh and Alizadeh 2011).

Chamomile products have a weak atropine-like effect, eliminate spasms of the abdominal organs, increase bile secretion and stimulate appetite. Chamazulene enhances regenerative processes, weakens allergic reactions, and has a local anesthetic effect. It is used for asthma, rheumatism, allergic gastritis and colitis, eczema treatment. Chamomile essential oil has a disinfecting effect, reduces gas formation, relieves pain, reduces inflammation, normalizes impaired functions of the gastrointestinal tract and intensifies perspiration (Nosov 2005; Srivastava et al. 2010; Miraj and Alesaeidi 2016).

Chamomile can be sown in spring (end of April - beginning of May), summer - autumn (end of August - beginning of September) and early winter (10-15 days before cold weather occurs). Spring sowing is the least reliable and is associated with the risk of getting sparse chamomile stands (Terekhin and Vandyshev 2008; Shklyarov 2016).

Some scientists indicate the advantages of $40-45 \mathrm{~cm}$ row spacing (Terekhin and Vandyshev 2008; Mordalski 2010; Kwiatkowski 2015; Shklyarov 2016) however, a maximum flower yield is formed when plants grow at 15, 20 and $30 \mathrm{~cm}$ row spacing (Singh et al. 2011). Triple rows every $25 \mathrm{~cm}$ by turns with $40-50 \mathrm{~cm}$ spacing $(40-25-25-40$ and $50-25-25-50 \mathrm{~cm}$ ) are the most favorable conditions for chamomile growth and yield (Surmacz-Magdziak 2011). The cultivation with $45 \mathrm{~cm}$ row spacing favors weed growth which suppresses chamomile development (Grigorieva 2003). On the other hand, narrow-row crops $(10 \mathrm{~cm})$ are the most competitive in relation to weed plants (Totskaya and Konon 2010). This medicinal crop requires special attention to weed infestation occurring at the early growth stages of the plants. The critical period for weed control (CPWC) is a period in the crop growth cycle during which weeds must be controlled to prevent yield losses.

Fast-growing species such as milk thistle [Silybum marianum (L.) Gaertn.], pot marigold (Calendula offici- nalis L.), German chamomile (Matricaria chamomilla L.), etc. overcome critical periods of crop development within 45-60 days after the beginning of seedling emergence (Zagumennikov 2002). Timing for weeding should be determined based on the sensitivity of the crop to the presence of weeds; values for maximum tolerance period, corresponding to the moment when weeding operations should start, and it has been determined as 30-45 days after sowing for ginger (Zingiber officinale Roscoe), and 24-38 for cumin (Cuminum cyminum L.). The CPWC in blond plantain (Plantago ovata Forssk.) (seeds) for $5 \%$ and $10 \%$ loss of yield was defined as 21-52 and 26-38 days after sowing, in sage (Salvia officinalis L.) (biomass) 22-98 and 25-85 days, respectively (Carrubba 2017).

The objective of our researches was to determine weed harmfulness in chamomile crops and to evaluate quality and quantity of yield and its correlation to different row spacing for spring sowing.

\section{Materiały i metody / Materials and methods}

The experiments were performed on the experimental field of the RUE "Institute for Plant Protection" (ac. Priluki, Minsk District $-53^{\circ} 79^{\prime} \mathrm{E}, 27^{\circ} 45^{\prime} \mathrm{N}$ ) in $2013-2014$ and 2016. Chamomile cultivar Podmoskovnaya crop was grown by direct seed sowing with $12.5 \mathrm{~cm}$ and $45 \mathrm{~cm}$ row spacing (28.04.2013, 21.04.2014, 15.04.2016). Harvesting of flowers was carried out manually with combs on 27.06.2013, 21.07.2014 and 29.06.2016.

The plots were weeded for the first time 20 days after sowing, and then every 10 days until 80 days after sowing. The total experimental area was $288 \mathrm{~m}^{2}$. The field experiment was designed in blocks in six replicates with a total plot area $-3 \mathrm{~m}^{2}$, registration plot area $-1 \mathrm{~m}^{2}$. The removed weeds were analyzed and the fresh vegetative mass of weeds from $1 \mathrm{~m}^{2}$ was determined. The phenological observations were carried out recording crop growth and development.

The air-dry fresh mass of chamomile plants was analyzed during harvest. The flowers (baskets) yield from each plot was dried in an electric dryer at $40^{\circ} \mathrm{C}$ and counted as airdry raw material in $\mathrm{kg} / \mathrm{ha}$. The data was evaluated by using analysis of variance (Dospekhov 1985).

The correlation of chamomile yield and the period of weed infestation was described using linear equation (computer programs Microsoft Excel):

$$
\mathrm{Y}=\mathrm{A}-\mathrm{BX}
$$

where:

$\mathrm{Y}$ - chamomile yield [kg/ha] (flower baskets),

A - the maximum possible yield with the complete absence of weeds in the crop [ $\mathrm{kg} / \mathrm{ha}$,

B - correlation coefficient, showing the crop yield changes per day considering the days after sowing, 
$\mathrm{X}$ - period of weed vegetation in chamomile crops, considering number of days after sowing.

The linear equation is the best function for expressing the relationship between crop weed infestation and the crop yield. With approximately the same degree of accuracy, it reflects the relationship between these indicators and favorably differs from the other mathematical models by the simplicity of calculations and the logical interpretation of the results.

The relative coefficient of weed species complex harmfulness is characterized by potential yield decrease expressed in percent (per day considering the days after sowing) has been determined by formula:

$$
\mathrm{B}_{0}=\mathrm{B} / \mathrm{A} \times 100 \times \mathrm{R}^{2}
$$

where:

$\mathrm{B}_{0}-$ relative coefficient of weed harmfulness in $\%$,

$\mathrm{R}^{2}$ - coefficient of determination.

The trials studying the effect of weeding periods on changes of biologically active substance contents in chamomile raw material (blue oil) were carried out at the Scientific Production Centre "BIOTEST" in accordance with the requirements of the State Pharmacopoeia of the Republic of Belarus II (Sheryakova 2008).
The collected results did not differ significantly among experimental years, therefore, the averages for 2013-2014 and 2016 are shown in the Table 1.

The annual rainfall totals in the period 2013-2016 during the chamomile growing seasons (May-August) differed. In April and July 2013-2014 the rainfall amount was not high, in May and June the rainfall amount increased; April and July 2016 were rather humid while May and June were rather dry. The air temperature during the years of performing the studies (April-August) was higher and the mean of temperatures for 1981-2010 are presented in Table 1.

Sielianinov's hydrothermic coefficient $(\mathrm{K})$ was calculated (Pavlova 1984) in order to get a more complete analysis of thermal and rainfall conditions:

$$
\mathrm{K}=\frac{\mathrm{R}}{0.1 \sum \mathrm{t}}
$$

where:

$\mathrm{R}$ - total rainfall for a given month [mm],

$\Sigma \mathrm{t}$ - the sum of mean temperatures for a given month $\left[{ }^{\circ} \mathrm{C}\right]$.

The analysis of the values of the hydrothermal coefficient calculated for the individual chamomile growing seasons shows (Table 2) that in 2013 and 2014 optimal conditions for the growth of this herbal plant were favored only in

Tabela 1. Opady i temperatura powietrza od kwietnia do sierpnia w latach 2013-2014, 2016 w porównaniu do średnich wartości z wielolecia (1981-2010) w Mińsku

\begin{tabular}{|c|c|c|c|c|c|c|c|}
\hline & \multirow{2}{*}{$\begin{array}{l}\text { Rok } \\
\text { Year }\end{array}$} & \multicolumn{6}{|c|}{ Miesiąc - Month } \\
\hline & & $\begin{array}{c}\text { kwiecień } \\
\text { April }\end{array}$ & $\begin{array}{l}\text { maj } \\
\text { May }\end{array}$ & $\begin{array}{l}\text { czerwiec } \\
\text { June }\end{array}$ & $\begin{array}{l}\text { lipiec } \\
\text { July }\end{array}$ & $\begin{array}{l}\text { sierpień } \\
\text { August }\end{array}$ & $\begin{array}{c}\text { średnio - mean } \\
\text { IV-VIII }\end{array}$ \\
\hline \multirow{4}{*}{$\begin{array}{c}\text { Opady } \\
\text { Rainfall } \\
{[\mathrm{mm}]}\end{array}$} & 2013 & 31.4 & 87.9 & 69.5 & 93.9 & 19.3 & 302.0 \\
\hline & 2014 & 32.8 & 80.3 & 68.3 & 55.6 & 168.3 & 405.3 \\
\hline & 2016 & 56.4 & 53.7 & 54.3 & 136.4 & 46.9 & 347.7 \\
\hline & $\begin{array}{c}\text { średnia - mean } \\
1981-2010\end{array}$ & 45.9 & 61.0 & 83.0 & 90.0 & 81.0 & 360.9 \\
\hline \multirow{4}{*}{$\begin{array}{c}\text { Temperatura } \\
\text { Temperature } \\
{\left[{ }^{\circ} \mathrm{C}\right]}\end{array}$} & 2013 & 6.6 & 16.7 & 19.3 & 18.6 & 18.2 & 15.9 \\
\hline & 2014 & 8.7 & 14.3 & 15.8 & 20.7 & 19.1 & 15.7 \\
\hline & 2016 & 8.3 & 15.4 & 18.8 & 19.5 & 18.7 & 16.1 \\
\hline & $\begin{array}{c}\text { średnia - mean } \\
1981-2010\end{array}$ & 5.5 & 12.7 & 16.0 & 17.7 & 16.3 & 13.6 \\
\hline
\end{tabular}

Table 1. Rainfall and air temperature in April-August of 2013-2014, 2016 as compared to the long-term means (1981-2010) in Minsk

Tabela 2. Współczynnik hydrotermiczny Sielaninova (K)

Table 2. Sielianinov's hydrothermic coefficient (K)

\begin{tabular}{c|c|c|c|c|c}
\hline \multirow{2}{*}{$\begin{array}{c}\text { Rok } \\
\text { Year }\end{array}$} & \multicolumn{5}{|c}{ Miesiąc - Month } \\
\cline { 2 - 6 } & Apriecień & $\begin{array}{c}\text { maj } \\
\text { May }\end{array}$ & $\begin{array}{c}\text { czerwiec } \\
\text { June }\end{array}$ & $\begin{array}{c}\text { lipiec } \\
\text { July }\end{array}$ & $\begin{array}{c}\text { sierpień } \\
\text { August }\end{array}$ \\
\hline 2013 & 1.6 & 1.8 & 1.2 & 1.7 & 0.4 \\
\hline 2014 & 1.3 & 1.9 & 1.4 & 0.9 & 2.9 \\
\hline 2016 & 2.3 & 1.2 & 1.0 & 2.3 & 0.8 \\
\hline $\begin{array}{c}\text { Średnia-Mean } \\
1981-2010\end{array}$ & 2.8 & 1.6 & 1.7 & 1.7 & 1.7 \\
\hline
\end{tabular}


May and June, while in April the rainfall amount was two times less than the average from many years data. In 2016 favorable hydrothermal conditions were recorded in April and July, while May and June were drier.

\section{Wyniki i dyskusja / Results and discussion}

The species composition of weeds in chamomile crops during the years of conducted studies consisted of annual dicotyledonous weeds - Thlaspi arvense L., Chenopodium album L., Stellaria media (L.) Vill., Galinsoga parviflora Cav. and Polygonum convolvulus L.
In 2013, chamomile seeds were sown on April 28. High temperatures in May and abundant amount of rainfall stimulated the growth of weeds and chamomile plants up to 10 days after sowing. The performed observations recorded the first pair of true leaves being formed on May 18, rosette on May 28, stem formation on June 7, budding stage was noted on June 17, and flowering on June 27.

In April 2014, the seed sowing was performed into warm soil, however, the lack of precipitation (within 20 days after sowing) resulted in less crop weed infestation and inhibited chamomile emergence. The crop growing season was prolonged. The observations regarding growth stages of chamomile plants noted the formation of the first

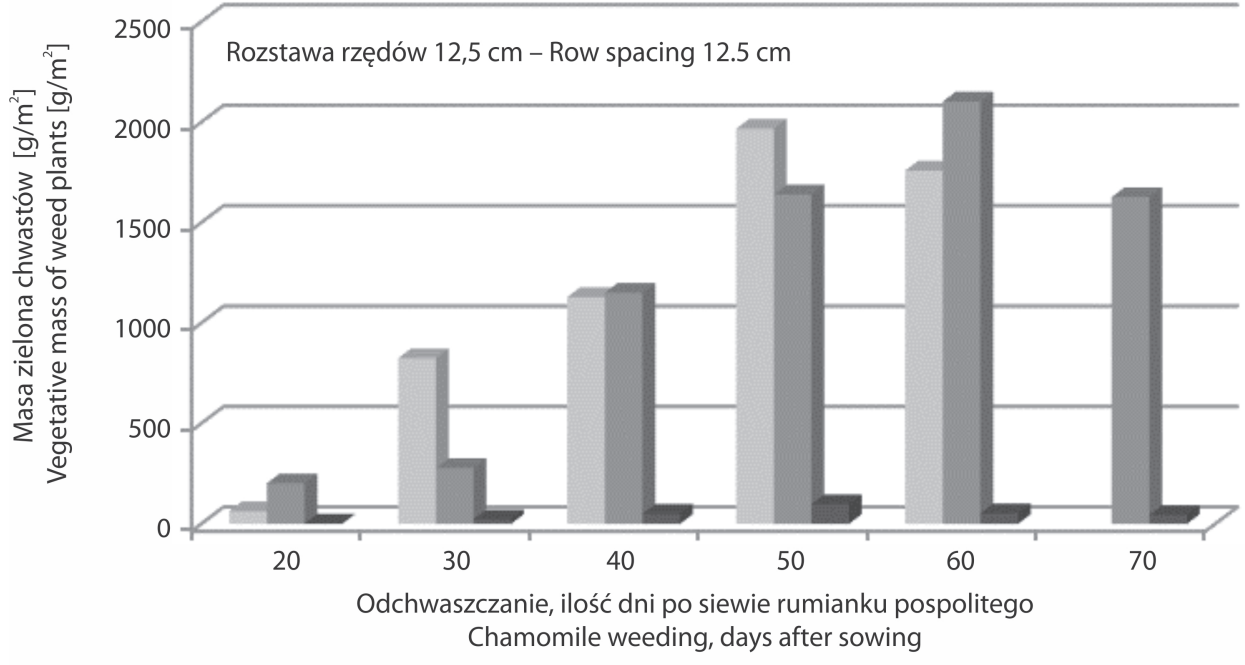

$2013 \square 2014 \square 2016$

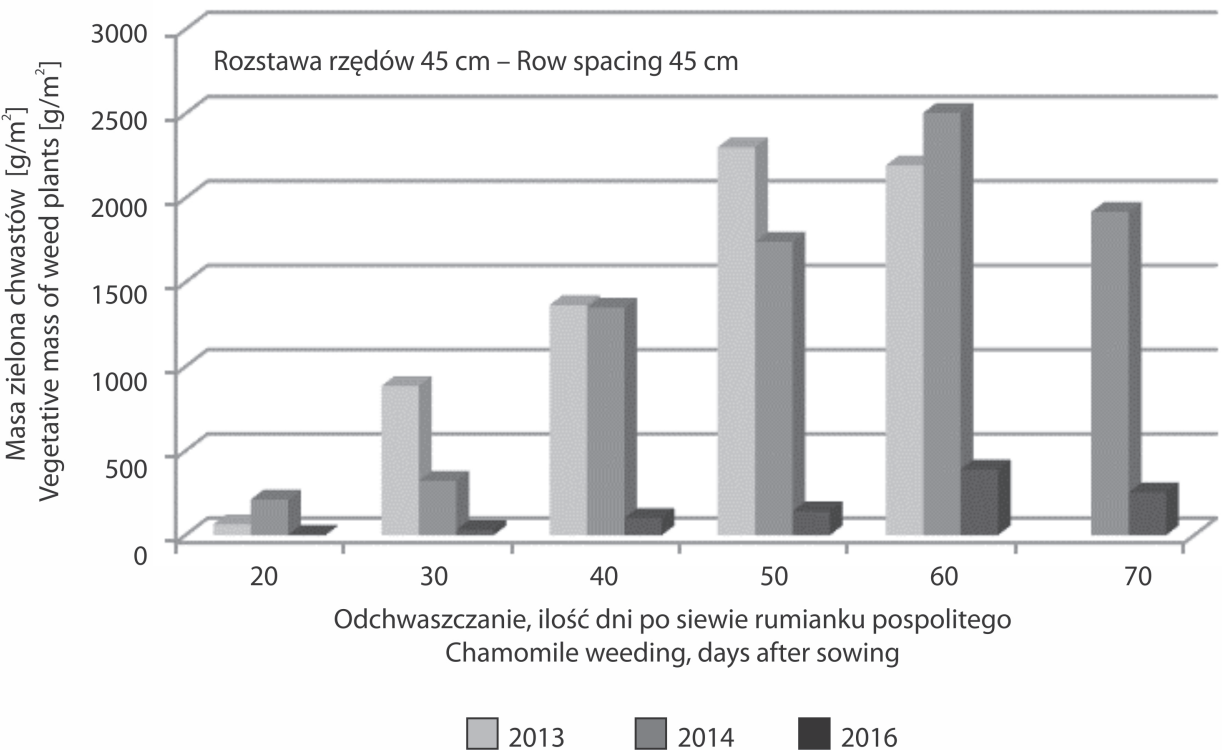

Rys. 1. Całkowita masa zielona chwastów w uprawie rumianku pospolitego (Matricaria chamomilla L.)

Fig. 1. Total vegetative mass of weeds in chamomile (Matricaria chamomilla L.) crops 
pair of true leaves on May 21, the second pairs of leaves on May 31, rosette on June 10, stem formation on June 20, budding on June 30, and beginning of flowering on July 10. The flower harvest was conducted on July 21 at full flowering stage of the crop, i.e. almost a month later than in 2013.

In 2016, the sowing was performed on April 15 and warm weather conditions enhanced appearance of shoots by May 3. The first pair of real leaves appeared on May 5, the second pair of leaves was recorded by May 10, 2-4 cm diameter rosette on May 15. At the beginning of June, stem formation was observed followed by budding on June 24 and finally flowering on June 29 and then the crop was harvested.

In 2013-2014 the maximum of mass of weeds occurred 40-60 after sowing (both methods) with a row spacing of $12.5 \mathrm{~cm}$ and it accounted on average 1140.0-1930.6 g/ $\mathrm{m}^{2}$,

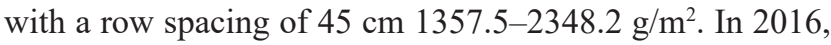
the mass of weeds was not high and ranged from 98.2 to $391.0 \mathrm{~g} / \mathrm{m}^{2}$, respectively. During chamomile flowering, a decrease in weed plant mass was recorded (Fig. 1).

Cultivation of chamomile with a row spacing of $12.5 \mathrm{~cm}$ suppressed the vegetative mass of weeds compared to the plants grown at $45 \mathrm{~cm}$ row spacing. On average, over three years, the mass of weeds when cultivating chamomile with a row spacing of $45 \mathrm{~cm}$ was 1.1-1.3 times higher than when cultivating it with a row spacing of $12.5 \mathrm{~cm}$.

In 2013 weed removal 30 days after sowing did not cause a significant effect on the crop yield. The yield from the crop with a row spacing of $45 \mathrm{~cm}$ and removal of weeds 40 days after sowing was decreased by $47.7 \%$ while with $50-60$ days after sowing removal of weeds by $54.9-59.7 \%$. The yield from the crop with 12.5 row spacing, removal of weeds 40 days after sowing resulted in the yield decrease by $42.5 \%$, while $50-60$ days after sowing by $45.1-46.6 \%$ (Table 3).
In 2014, with both methods of sowing, the presence of weeds 30-40 days after sowing did not affect the chamomile flower yield. Weed removal at row distance of 12.5 and $45 \mathrm{~cm} 50$ days after sowing resulted in a significant drop in the yield (30.7 and 77.4\%). When weeding took place at a later date, the flower yield loss was 41.9-60.1 and 94.5-98.7\%, respectively.

In 2016, a decrease in chamomile flower yield (18.0\%) with a row distance of $45 \mathrm{~cm}$ was observed with weed removal 30 days after sowing. Longer competition of chamomile plants with removal of weeds (40 days after sowing) resulted in the flower crop loss by $33.8 \%$. Removing of weeds 50-60 days after sowing caused the yield shortage by $64.5-67.8 \%, 70$ days $-70.6 \%$ of the flower yield loss. Chamomile growing with the narrower row spacing $(12.5 \mathrm{~cm})$ allowed weeds to compete more. Weed removal 30 days after sowing also did not cause a significant effect on the crop yield. The removal of weeds 40 days after sowing resulted in the yield decreased by $21.2 \%$, while $50-60$ days after sowing by $53.5-62.3 \%$, and 70 days $64.5 \%$.

The flower yield of the wider row distance was lower compared with the narrower row spacing crops. The average yield from the crop with a row spacing of $12.5 \mathrm{~cm}$ amounted to $579.3 \mathrm{~kg} / \mathrm{ha}$, with a row of $45 \mathrm{~cm}$ to $402.1 \mathrm{~kg} / \mathrm{ha}$.

On the average, the three-year yield from the crops cultivated with the row distance of $12.5 \mathrm{~cm}$ decreased by $24.0 \%$ for weed control carried out 40 days after sowing, $43.8 \%$ for 50 days after sowing and $50.8 \%$ for 60 days after sowing. The losses of chamomile flower yield were slightly higher for the crop grown at the row sowing of $45 \mathrm{~cm}$ and a decrease amounted to $30.8 \%$ (40 days), $66.0 \%$ (50 days) and $74.0 \%$ (60 days).

Based on the obtained data, a correlation was determined between the days of weed vegetation after sowing date and

Tabela 3. Plon kwiatów rumianku pospolitego (Matricaria chamomilla L.) w zależności od terminu odchwaszczania Table 3. Yield of chamomile (Matricaria chamomilla L.) flowers in correlation to weeding time

\begin{tabular}{|c|c|c|c|c|c|c|c|c|}
\hline \multirow{3}{*}{$\begin{array}{l}\text { Ilość dni po siewie } \\
\text { Days after sowing }\end{array}$} & \multicolumn{8}{|c|}{$\begin{array}{c}\text { Plon }[\mathrm{kg} / \mathrm{ha}] \text { w zależności od rozstawy rzędów }[\mathrm{cm}] \\
\text { Yield }[\mathrm{kg} / \mathrm{ha}] \text { depending on row spacing }[\mathrm{cm}]\end{array}$} \\
\hline & \multicolumn{2}{|c|}{2013} & \multicolumn{2}{|c|}{2014} & \multicolumn{2}{|c|}{2016} & \multicolumn{2}{|c|}{ średnio - average } \\
\hline & 12.5 & 45 & 12.5 & 45 & 12.5 & 45 & 12.5 & 45 \\
\hline 20 & 592.5 & 325.0 & 524.7 & 379.4 & 620.6 & 501.9 & 579.3 & 402.1 \\
\hline 30 & 601.7 & 335.8 & 542.2 & 376.9 & 568.6 & 411.6 & 570.8 & 374.8 \\
\hline 40 & 340.8 & 170.0 & 490.5 & 332.3 & 488.9 & 332.0 & 440.1 & 278.1 \\
\hline 50 & 325.0 & 146.7 & 363.7 & 85.7 & 288.9 & 178.0 & 325.9 & 136.8 \\
\hline 60 & 316.7 & 130.8 & 304.7 & 20.9 & 234.1 & 161.5 & 285.2 & 104.4 \\
\hline 70 & - & - & 221.7 & 5.3 & 220.1 & 147.5 & - & - \\
\hline 80 & - & - & 209.3 & 5.1 & - & - & - & - \\
\hline $\begin{array}{l}\operatorname{NIR}(0,05) \\
\operatorname{LSD}(0.05)\end{array}$ & 124.67 & 93.36 & 145.21 & 123.35 & 86.20 & 72.60 & - & - \\
\hline
\end{tabular}


chamomile flower yield. It was defined that the correlation coefficient during the chamomile years of vegetation between them was quite strong $(\mathrm{R}=0.89-0.97)$. The relative harmfulness coefficient indicates that for the crops with a row spacing of $45 \mathrm{~cm}$, the correlation was $1.06-1.19 \%$ (average 1.34\%) and exceeded the coefficient obtained for the crops with narrower row spacing $(12.5 \mathrm{~cm})$ when this value was $0.85-1.05 \%$ (average $1.02 \%$ ). This means that flower yield losses from weeds in wider row spacing are higher (Table 4).

In 2013-2014 chamomile vegetative mass at row spacing of $12.5 \mathrm{~cm}$ decreased with the weed competition in 40 days, in 2016 - in 50 days after sowing. At row spacing of $45 \mathrm{~cm}$ chamomile mass decrease was observed 40 days after sowing (2013), 50 days after sowing (2014) and 30 days after sowing (2016). On the average, at row spacing $12.5 \mathrm{~cm}$ a raw vegetative chamomile plants mass decrease was $19.7 \%$ (40 days) and 39.6-46.2\% (50-60 days after sowing), $45 \mathrm{~cm}-33.2 \%$ and $67.3-72.4 \%$ (Fig. 2).

Blue essential oil content in chamomile flowers based on dry raw material ranged from 3.61 to $4.78 \mathrm{ml} / \mathrm{kg}$ in 2013 , from 5.05 to $5.49 \mathrm{ml} / \mathrm{kg}$ in 2014 . The dependence between the timing of weed removal and biologically active substances content in chamomile flowers was identified. Trait variation between the variants at different periods of weed removal in chamomile crops is insignificant and makes at row distance of $45 \mathrm{~cm} 0.01-0.05 \mathrm{ml} / \mathrm{kg}$ and $0.22-0.27 \mathrm{ml}$ with a row spacing of $12.5 \mathrm{~cm}$ (Table 5).

Tabela 4. Korelacja pomiędzy plonem rumianku pospolitego (Matricaria chamomilla L.) a długością wegetacji chwastów w uprawie Table 4. Correlation between chamomile (Matricaria chamomilla L.) yield and duration of weeds growing in the crop

\begin{tabular}{|c|c|c|c|}
\hline $\begin{array}{l}\text { Rok } \\
\text { Year }\end{array}$ & $\begin{array}{l}\text { Równanie regresji liniowej } \\
\text { Linear regression equation }\end{array}$ & $\begin{array}{c}\text { Współczynnik } \\
\text { korelacji R } \\
\text { Correlation coefficient R }\end{array}$ & $\begin{array}{c}\text { Względny współczynnik } \\
\text { szkodliwości B0 [\%] } \\
\text { Harmfulness relative } \\
\text { coefficient B0 [\%] }\end{array}$ \\
\hline \multicolumn{4}{|c|}{ Rozstawa rzędów - Row spacing - $12.5 \mathrm{~cm}$} \\
\hline 2013 & $\mathrm{Y}=766.67-8.28 \mathrm{X}$ & 0.89 & 0.85 \\
\hline 2014 & $Y=696.10-6.33 X$ & 0.97 & 0.85 \\
\hline 2016 & $\mathrm{Y}=815.72-9.16 \mathrm{X}$ & 0.97 & 1.05 \\
\hline $\begin{array}{l}\text { Średnio } \\
\text { Average }\end{array}$ & $Y=773.48-8.33 X$ & 0.97 & 1.02 \\
\hline \multicolumn{4}{|c|}{ Rozstawa rzędów - Row spacing - $45 \mathrm{~cm}$} \\
\hline 2013 & $\mathrm{Y}=452.67-5.78 \mathrm{X}$ & 0.91 & 1.06 \\
\hline 2014 & $Y=561.07-7.78 X$ & 0.93 & 1.19 \\
\hline 2016 & $Y=632.92-7.65 X$ & 0.96 & 1.12 \\
\hline $\begin{array}{l}\text { Średnio } \\
\text { Average }\end{array}$ & $Y=592.61-8.33 X$ & 0.97 & 1.34 \\
\hline
\end{tabular}

Y - plon rumianku pospolitego (Matricaria chamomilla L.) (sucha masa) [kg/ha] - chamomile yield (dry raw material) [kg/ha] $\mathrm{X}$ - długość wegetacji chwastów w uprawie (ilość dni po siewie) - duration of weed vegetation in the crop (days after sowing)

Tabela 5. Wpływ terminu odchwaszczania rumianku pospolitego (Matricaria chamomilla L.) na jakość suchej masy Table 5. Influence of weeding time on chamomile (Matricaria chamomilla L.) dry raw material quality

\begin{tabular}{|c|c|c|c|c|c|c|c|c|}
\hline \multirow{3}{*}{$\begin{array}{l}\text { Ilość dni } \\
\text { po siewie } \\
\text { Days after } \\
\text { sowing }\end{array}$} & \multicolumn{6}{|c|}{$\begin{array}{c}\text { Zawartość olejku eterycznego w suchej masie }[\mathrm{ml} / \mathrm{kg}] \\
\text { w zależności od rozstawy rzędów }[\mathrm{cm}] \\
\text { Blue essential oil content in dry raw material }[\mathrm{ml} / \mathrm{kg}] \\
\text { in correlation to row spacing }[\mathrm{cm}]\end{array}$} & \multirow{2}{*}{\multicolumn{2}{|c|}{$\begin{array}{c}\text { Wydajność na jednostkę } \\
\text { powierzchni } \\
\text { Output per unit area } \\
{[\mathrm{ml} / \mathrm{ha}]}\end{array}$}} \\
\hline & \multicolumn{2}{|c|}{2013} & \multicolumn{2}{|c|}{2014} & \multicolumn{2}{|c|}{ średnio - average } & & \\
\hline & 12.5 & 45 & 12.5 & 45 & 12.5 & 45 & 12.5 & 45 \\
\hline 20 & 4.00 & 4.78 & 5.18 & 5.48 & 4.59 & 5.13 & 2658.8 & 2062.9 \\
\hline 30 & 3.61 & 4.71 & 5.12 & 5.49 & 4.37 & 5.10 & 2491.5 & 1911.4 \\
\hline 40 & 4.64 & 4.69 & 5.07 & 5.47 & 4.86 & 5.08 & 2136.6 & 1412.8 \\
\hline 50 & 4.63 & 4.75 & 5.05 & 5.49 & 4.84 & 5.12 & 1577.1 & 700.4 \\
\hline 60 & 4.30 & 4.76 & 5.06 & 5.49 & 4.68 & 5.13 & 1334.5 & 535.1 \\
\hline
\end{tabular}



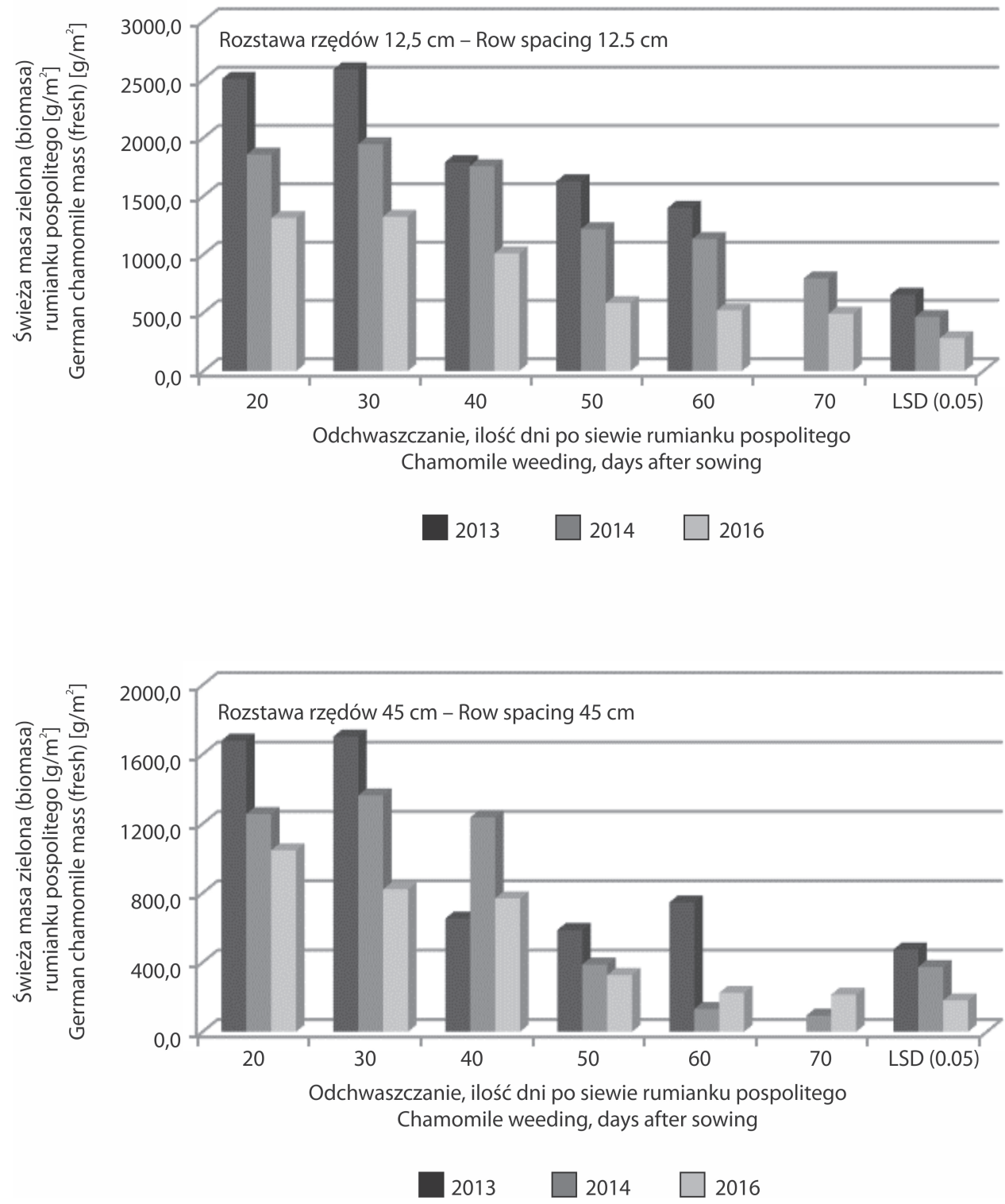

Rys. 2. Redukcja masy zielonej (biomasy) rumianku pospolitego (Matricaria chamomilla L.) w zależności od terminu odchwaszczania Fig. 2. Chamomile vegetative mass decrease by weeding, days after sowing

In 2013-2016 with a width of $12.5 \mathrm{~cm}$, the essential oil output (ml/ha) decreased by $19.6 \%$ (40 days), $40.7 \%$ (50 days) and $49.8 \%$ (60 days); with a width of $45 \mathrm{~cm}$, its decrease was noted by $31.5 \%$ for 40 days, by $66.0 \%$ for 50 days and $74.1 \%$ for 60 days after chamomile sowing. However, yield capacity and blue essential oil content in flower dry raw material per area unit is significantly higher at the narrower row spacing $(12.5 \mathrm{~cm})$.

\section{Wnioski / Conclusions}

1. Weed presence during 20-30 days after sowing did not reduce chamomile flower yield (row spacing of 12.5 and $45 \mathrm{~cm}$ ). Chamomile flower crop losses were $24.0 \%$ for 40 days after sowing (row spacing of $12.5 \mathrm{~cm}$ ) and $30.8 \%$ (row spacing of $45 \mathrm{~cm}$ ), for 50 days after sowing the losses amounted to $43.8-66.0 \%$. Sixty days after sowing and a row spacing of $12.5 \mathrm{~cm}$ and $45 \mathrm{~cm}$, the crop losses were $50.8 \%$ and $74.0 \%$, accordingly. In some cases, the flower yield was entirely lost.

2. The competition of chamomile plants with weeds negatively affected the vegetative plant mass 40 days after sowing (from 25.3 to $57.0 \%$ ).

3. The essential oil output per unit area for the crop with a row distance of $12.5 \mathrm{~cm}$ decreased by $19.6 \%$ at 40 days after sowing, $40.7 \%$ at 50 days and $49.8 \%$ at 60 days. Its decrease for the crop with a row distance of $45 \mathrm{~cm}$ was $31.5 \%$ at 40 days after sowing, $66.0 \%$ at 50 days and $74.1 \%$ at 60 days after chamomile sowing.

4. The correlation coefficient between the days of weed vegetation after sowing date and chamomile yield was 
quite strong $(\mathrm{R}=0.89-0.97)$. The relative harmfulness coefficient was $1.34 \%$ (row spacing of $45 \mathrm{~cm}$ ) and exceeded the coefficient $(1.02 \%)$ obtained for the crops cultivated with narrower row spacing $(12.5 \mathrm{~cm})$.
5. Chamomile crops grown with a row spacing of $12.5 \mathrm{~cm}$ are more competitive with weeds than the crops with a row spacing of $45 \mathrm{~cm}$. A suppression of weed growth in particular (within wider row spacing crops, their weight is $1.1-1.3$ times higher) and their harmfulness.

\section{Literatura / References}

Carrubba A. 2017. Weed and weeding effects on medicinal herbs. s. 295-327. W: Medicinal Plants and Environmental Challenges (M. Ghorbanpour, A. Varma, red.). Springer International Publishing, 426 ss. DOI: 10.1007/978-3-319-68717-9_17

Dospekhov B.A. 1985. Metodika polevogo opyta (s osnovami statisticheskoy obrabotki rezultatov issledovanij). [Field trial methods (with the fundamentals of statistic results processing)]. Agropromizdat, Moskow, 351 ss.

Grigorieva N.A. 2003. Biologicheskie osobennosti vozdelyvaniya kalenduly lekarstvennoy i romashki aptechnoy pri minimalnykh zatratakh truda, bez primeneniya sredstv khimizatsii. [Biological features of calendula officinalis and German chamomile cultivation at the minimum cost of manual labor, without the use of chemicals]. Extended abstract of candidate's thesis. Moskow, 24 ss.

Kwiatkowski C.A. 2015. Yield and quality of chamomile (Chamomilla recutita (L.) Rausch.) raw material depending on selected foliar sprays and plant spacing. [Plon i jakość surowca rumianku pospolitego (Chamomilla recutita (L.) Rausch.) w zależności od wybranych preparatów dolistnych oraz rozstawy roślin]. Acta Scientiarum Polonorum, Hortorum Cultus 14 (1): 143-156.

Miraj S.A., Alesaeidi S. 2016. A systematic review study of therapeutic effects of Matricaria recuitta chamomile (chamomile). Electronic Physician 8 (9): 3024-3031. DOI: 10.19082/3024

Mordalski R. 2010. Rumianek pospolity [Chamomilla recutita (L.) Rauschert.]. s. 377-381. W: Uprawa ziół: poradnik dla plantatorów (B. Kołodziej, red.). Państwowe Wydawnictwo Rolnicze i Leśne, Poznań, 480 ss.

Nosov A.M. 2005. Lekarstvennye rasteniya ofitsialnoy i narodnoy mediciny. [Medicinal plants of official and traditional medicine]. Eksmo, Moskow: 549-555.

Pavlova M.D. 1984. Praktikum po agrometeorologii. [Practical aid in agricultural meteorology]. Gidrometeoizdat, Leningrad, 184 ss.

Sharafzadeh S., Alizadeh O. 2011. German and Roman chamomile. Journal of Applied Pharmaceutical Science 1 (10): 1-5.

Sheryakova A.A. (red.). 2008. Kontrol kachestva lekarstvennykh veshchestv i lekarstvennogo rastitelnogo syriya: Gosudarstvennaya Farmakopeya Respubliki Belarus. [Quality control of medicinal substances and medicinal plant raw material: The State Pharmacopoeia of the Republic of Belarus]. (Vol. 1-3, Vol. 2). Pobeda, Molodechno, 472 ss.

Shklyarov A.P. 2016. Promyshlennoe vyrashchivanie romashki aptechnoj. [The bindustrial German chamomile growing]. Nashe selskoe khozyaistvo 19: 32-34.

Singh O., Khanam Z., Srivastava M.K. 2011. Chamomile (Matricaria chamomilla L.): An overview. Pharmacognosy Review 5 (9): $82-95$. DOI: $10.4103 / 0973-7847.79103$

Srivastava J.K., Shankar E., Gupta S. 2010. Chamomile: A herbal medicine of the past with bright future. Molecular Medicine Reports 3 (6): 895-901. DOI: $10.3892 / \mathrm{mmr} .2010 .377$

Surmacz-Magdziak A. 2011. Influence of row spacing on herb yield of common chamomile (Chamomilla recutita (L.) Rausch.) as well as seed yield and quality. [Wpływ rozstawy rzędów na plon ziela rumianku pospolitego [Chamomilla recutita (L.) Rausch.] oraz plon i jakość nasion. Acta Agrobotanica 64 (3): 35-38.

Terekhin A.A., Vandyshev V.V. 2008. Tekhnologiya vozdelyvaniya lekarstvennykh rasteniy. [Technology of medicinal plants cultivation: manual]. RUDN, Moskow: 149-153.

Totskaya S.A., Konon N.T. 2010. Osobennosti tekhnologii vozdelyvaniya romashki aptechnoj (Matricaria chamomila L.) na semena. [Peculiarities of German chamomile (Matricaria chamomila L.) cultivation technology for seeds]. Izvestiya of Timiryazev Agricultural Academy 2: 91-98.

Upadhyaya R.K., Singh V.R., Tewari S.K. 2016. New agro-technology to increase productivity of chamomile (Matricaria chamomilla L.). Industrial Crops and Products 89: 10-13. DOI: 10.1016/j.indcrop.2016.04.072

Zagumennikov V.B. 2002. Osobennosti kultivatsii lekarstvennykh rastenij v Nechernoziomnoj zone RF. [Features of medicinal plants cultivation in the non-chernozem zone of the Russian Federation]. Extended abstract of Doctor's thesis. Moskow, 54 ss. 